medRxiv preprint doi: https://doi.org/10.1101/2021.04.25.21256082; this version posted May 7, 2021. The copyright holder for this preprint (which was not certified by peer review) is the author/funder, who has granted medRxiv a license to display the preprint in perpetuity.

It is made available under a CC-BY-NC-ND 4.0 International license .

\title{
Quarantine and testing strategies for safe pandemic travel
}

Chad R. Wells ${ }^{1}$, Jeffrey P. Townsend ${ }^{2,3,4,5 *}$, Abhishek Pandey ${ }^{1}$, Meagan C. Fitzpatrick ${ }^{1,6}$, William S. Crystal ${ }^{7}$, Seyed M. Moghadas, ${ }^{8}$ Alison P. Galvani ${ }^{1,3}$

${ }^{1}$ Center for Infectious Disease Modeling and Analysis (CIDMA), Yale School of Public Health, New Haven, Connecticut 06520, USA

${ }^{2}$ Department of Biostatistics, Yale School of Public Health, New Haven, Connecticut 06510, USA

${ }^{3}$ Department of Ecology and Evolutionary Biology, Yale University, New Haven, Connecticut 06525, USA

${ }^{4}$ Program in Computational Biology and Bioinformatics, Yale University, New Haven, Connecticut 06511, USA

${ }^{5}$ Program in Microbiology, Yale University, New Haven, Connecticut 06511, USA

${ }^{6}$ Center for Vaccine Development and Global Health, University of Maryland School of Medicine, Baltimore, Maryland, 21201, USA

${ }^{7}$ Yale College, New Haven, CT 06520

${ }^{8}$ Agent-Based Modelling Laboratory, York University, Toronto, Ontario, Canada

These authors contributed equally: Chad R. Wells and Jeffrey P. Townsend

*Corresponding author: Jeffrey.Townsend@Yale.edu 


\section{Abstract}

Background: Strict travel restrictions have been imposed by numerous countries and have contributed to the large socioeconomic burden of the COVID-19 pandemic. The long quarantines that are applicable to contacts of cases may be excessive for travel policy.

Methods: We developed an approach to evaluate imminent countrywide COVID-19 infections after 0-14-day quarantine and testing compared to travel ban, identifying the minimum quarantine duration for travelers from an origin country that did not increase the infection rate within the destination country as "sufficient." We integrated prevalence, daily incidence, vaccine coverage, immunity, age demographics, and travel flow for 31 European countries.

Findings: For the vast majority of country pairs, no testing, testing alone, or short quarantine were as effective as travel ban. Sufficient quarantines were predominantly influenced by disease prevalence and travel asymmetries. Analysis of the widespread variant of concern B.1.1.7 yielded similar results as for nonspecific viral incidence, whereas application to the heterogeneously distributed B.1.351variant required longer, more idiosyncratic quarantines. Adaptation to the European Union traffic-light risk stratification provided a simplified policy tool. Hospitalization rates were far more sensitive to countrywide vaccination coverage than to the duration of the travel quarantine or to the country of origin. Our analytical approach provides rigorous guidance for travel policy during early and late phases of pandemic disease.

Interpretation: For nearly half of country pairs analysed, travel can be permitted in the absence of quarantine and testing without increasing short-term infection rates; for the majority of origin-destination pairs requiring controls, a three-day or shorter quarantine with RT-PCR or antigen testing on exit suffices. These travel quarantine durations are substantially shorter than those specified for traced contacts.

Funding: EasyJet (JPT and APG), the Elihu endowment (JPT), the Burnett and Stender families' endowment (APG), the Notsew Orm Sands Foundation (JPT and APG), and the National Institutes of Health (MCF).

Keywords: SARS CoV-2, RT-PCR test, antigen test, tourism, travel quarantine 
medRxiv preprint doi: https://doi.org/10.1101/2021.04.25.21256082; this version posted May 7, 2021. The copyright holder for this preprint (which was not certified by peer review) is the author/funder, who has granted medRxiv a license to display the preprint in perpetuity.

It is made available under a CC-BY-NC-ND 4.0 International license .

\section{Research in context}

Evidence before this study: Evidence from early in the pandemic indicates that border closures at the epicenter slowed global dissemination of COVID-19. As community transmission became established in many nations, studies have suggested that the benefit of strict border closures in mitigating the transmission of disease from travellers diminished. Research for community settings has shown that testing later during quarantine, rather than upon entry to, can substantially shorten the duration of quarantine needed to reduce post-quarantine transmission.

Added value of this study: No study has evaluated the effect of quarantine durations in the context of international travel, or for specific pairs of origin and destination countries. By accounting for prevalence, daily incidence, vaccine coverage, immunity, age demographics, and travel flow between countries, we quantified the contribution of travel towards imminent infections in the destination country under different quarantine and testing strategies. We developed a framework to identify quarantine and testing strategies that enable travel from specific origins without increasing their infection and hospitalization rates in the destinations. For travel between 31 European countries, our results demonstrate that there are often less burdensome quarantine and testing strategies that can serve as equivalent alternatives to strict border closure. Specifically, these sufficient quarantine durations are especially dependent on COVID-19 prevalence within the two countries and the asymmetry in the travel flow. Using data on variants of concern, we found whether a border control strategy is sufficient to limit variant spread depends strongly on their geographical distribution. Our framework is applicable not just for international travel, but can be applied at any spatial or population scale within which movement restrictions could feasibly be implemented.

Implications of all available evidence: Travel quarantine and testing strategies can effectively mitigate importation and onward transmission within the country. Identifying these sufficient strategies can allow countries to permit travel with other countries, without risking an increase in their short-term infection rates. Once community transmission of disease or disease variants is ongoing, the long-term epidemic trend within the destination country is more apt to be determined by other disease control measures, e.g., contact tracing, vaccination, and non-pharmaceutical interventions. Together, travel quarantine and other related control measures can mitigate the risk of transmission between countries; limiting the threat of variants of concern. 
medRxiv preprint doi: https://doi.org/10.1101/2021.04.25.21256082; this version posted May 7, 2021. The copyright holder for this preprint (which was not certified by peer review) is the author/funder, who has granted medRxiv a license to display the preprint in perpetuity.

It is made available under a CC-BY-NC-ND 4.0 International license .

\section{Introduction}

Quarantine of travelers to prevent the importation of disease has been a cornerstone of efforts to prevent infectious disease since at least the fourteenth century [1]. Ongoing efforts to limit the importation and global dissemination of COVID-19 cases have included the imposition of strict national border control measures, typically mandating an extensive quarantine. These restrictions mitigated the spread of SARS-CoV-2 to unafflicted nations [2]. However, border closures at the epicenter only minimally delayed global spread [3], border restrictions and extended quarantines have had diminishing effects as the pandemic has progressed [4-6], and these interventions carry a large socioeconomic burden. A policy that enables safe travel between countries and shortens travel quarantine without increasing the country-specific infection rate would aid in the rejuvenation of the international economy.

Quarantine duration has traditionally been set with the objective of ensuring prevention of post-quarantine transmission with or without testing [7]. Such a goal is reasonable for those entering a country experiencing zero or near-zero prevalence of disease [8], or for a traced contact with a high chance of being infected. For example, the World Health Organization recommends a 14-day quarantine of exposed individuals to mitigate onward transmission from cases who have extended incubation periods $[9,10]$. However, travelers are typically far less likely to have been infected than traced contacts; if disease prevalence in their origin country is not substantially elevated in comparison to their destination, then their risk of transmitting is presumably equivalent to residents of the destination country who are following the same country-specific public health precautions. Because international travel is generally considered a desirable activity for diverse socioeconomic reasons, it would be reasonable for border controls in these global pandemic scenarios to have the objective not of preventing any transmission of pandemic disease by travelers—which, after all, is typically exchangeable in impact with transmission by residents - but instead of ensuring that travel does not cause a net increase in disease compared to border closure or complete ban of travel. Because sufficient quarantine and testing at the border can decrease in-country post-quarantine transmission to arbitrarily low levels [7,11], and infected individuals departing the country diminish in-country transmission, such a balance should be determinable.

Questions regarding the efficacy of travel quarantine and testing have recently been brought to the fore by the emergence of variants of concern of SARS CoV-2 (VOCs). Some VOCs are more transmissible than previous strains [12], 
medRxiv preprint doi: https://doi.org/10.1101/2021.04.25.21256082; this version posted May 7, 2021. The copyright holder for this preprint (which was not certified by peer review) is the author/funder, who has granted medRxiv a license to display the preprint in perpetuity.

It is made available under a CC-BY-NC-ND 4.0 International license .

and there is uncertainty regarding the extent of protection provided by natural and vaccine acquired immunity against each VOC [13-15]. VOC emergence has spurred the renewal of border closures, long quarantines, and extensive COVID-19 testing to prevent VOCs from establishing in unaffected countries [4]. Impeding the establishment of VOCs with an appropriate travel quarantine strategy could provide time for vaccine coverage to be scaled up, limiting overall transmission [16]. However, it is unclear what travel quarantine and testing strategies are sufficient to reduce the seeding of new VOC cases. Therefore, knowledge of the potential suppressive effects of travel quarantine and testing on prevalence of known VOCs is important to limiting the resurgence of the disease, and should be considered in the specification of country-specific and individualized travel quarantine strategies.

Here we integrate analytical approaches for the calculation of post-quarantine transmission [7] with a model of country-specific imminent infections (i.e., new infections generated from the daily net change in infected individuals) to identify travel quarantine and testing strategies that will not increase infections in the destination country compared to a strategy of complete border closure. For quantifying the duration of travel quarantine among each pair of 31 countries in Europe, we incorporate the travel flow between countries, country-specific age structure, seroprevalence, and vaccine coverage and efficacy. We also generalize the analysis to provide quarantine and testing strategies based on EU traffic-light stratification of COVID-19 risk instead of country-specific strategies. Lastly, we examine the consequences of these strategies for hospitalization rates.

\section{Results}

Conservatively assuming long-term stays (i.e., prevalence in travelers was assumed to rise to the prevalence in the country visited by the time of return) and parameterizing with data specifying a basic reproduction number of 2.5 [7], age-dependent symptomatic disease [17], vaccine efficacy [18] and country-specific coverage [19], an incubation period of 8.29 days [7,20,21], and isolation upon symptom onset [7], we derived theory enabling the calculation of sufficient quarantines - the minimum travel quarantine duration with and without RT-PCR and antigen testing such that the number of imminent infections remains equivalent or lower than that estimated under border closure (Fig. 1; Methods). For each available pairing of 31 European countries, we defined the country to which individuals travel as the destination country, and the country of departure as the origin country. Utilizing reported daily incidence [22], vaccine coverage [19], 
country-specific age demographics [23], and 2019 pairwise travel flow [24-34] (Table S1-S2), we calculated a sufficient quarantine with an RT-PCR test conducted on exit at which daily imminent infections would not exceed those in the destination country if travel were not permitted. If the sufficient quarantine duration exceeded 14 days, we indicated a travel ban by the destination country from the origin country. Furthermore, we classified countries based on the European Union (EU) system for COVID-19 travel restrictions [35]. This system stratifies countries based on reported caseload over the preceding two weeks: i) $<25$ cases (Green); ii) 25-150 cases (Amber); iii) 150-500 cases (Red); and iv) $>500$ cases

(Dark Red), per 100,000 residents.

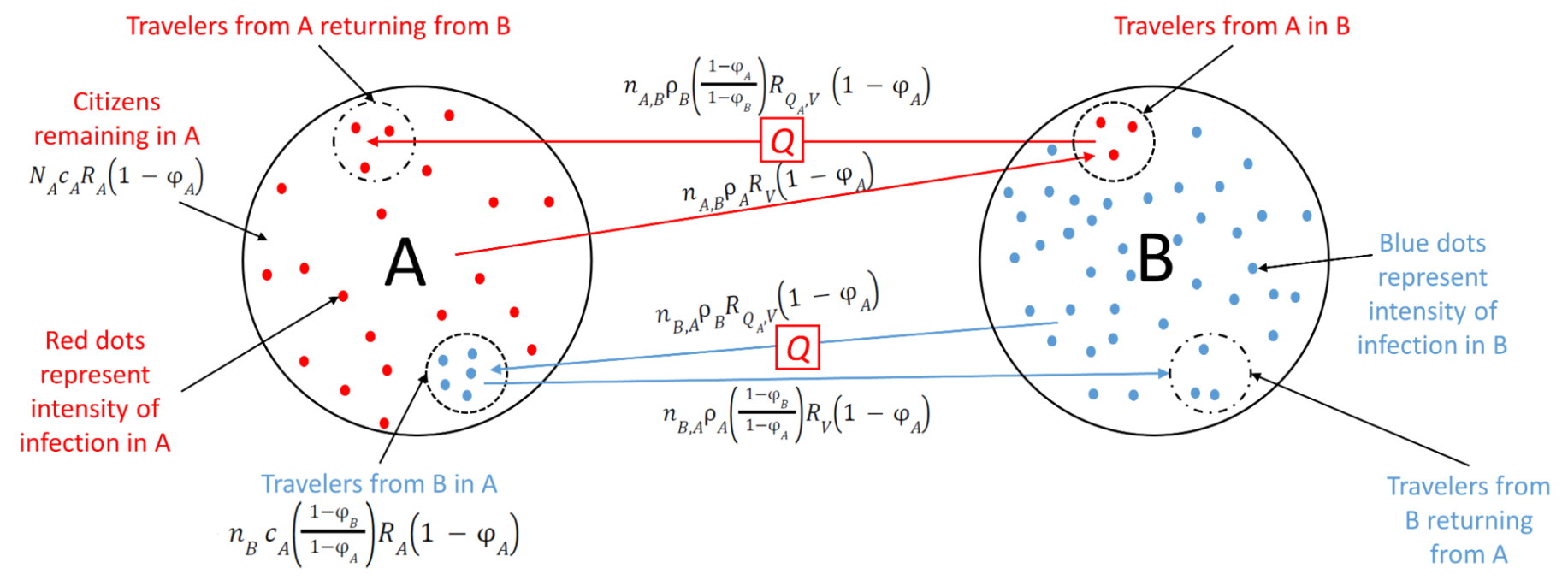

Figure 1. Model schematic diagram for imminent infections and travel quarantine. With travel between country $\mathrm{A}$ (red) and country $B$ (blue), the travel quarantine specified by country $A$ is dependent on the intensity of infection in both country $A$ and $B$, the number of residents leaving country $A$ for country $B$, the number of travellers entering country $A$ from country $B$, the number of residents returning to country $A$, and the number of travellers from country $B$ returning to country $B$. In the most general instantiation of our model, the minimum duration of travel quarantine is dependent on the number of daily travellers from country $A$ to country $\mathrm{B}, n_{A B}$, the number of daily travellers from country $\mathrm{B}$ to country $\mathrm{A}$, $n_{B A}$, the country-specific prevalence of non-isolated infections $\varrho$, country-specific immunity $\varphi$, the number of travellers from country $B$ abroad in country $A, n_{B}$, the number of citizens of $A$ who are non-travellers and not quarantined, $N_{A}$, daily fractional incidence, $c$. The amount of remaining transmission $\left(R_{A}, R_{V}, R_{Q v, v}\right)$ is calculable based on virus- or variant-specific properties and the temporal infectivity and test sensitivity [7].

\section{Country-specific quarantines}

Evaluation on the basis of our full model with all parameters as of April 12, 2021 yielded quarantine and testing regimes sufficient to enable travel without increasing within-country transmission (Fig. 2). By following country-specific travel quarantine strategies that are individualized for origin and destination pairs, we found that travel can be allowed 
medRxiv preprint doi: https://doi.org/10.1101/2021.04.25.21256082; this version posted May 7, 2021. The copyright holder for this preprint (which was not certified by peer review) is the author/funder, who has granted medRxiv a license to display the preprint in perpetuity. It is made available under a CC-BY-NC-ND 4.0 International license.

among most pairings without increasing the imminent infections in the destination country (Fig 2, Fig S1). Countries with lower prevalences of disease tended to require more stringent regimes of quarantine and testing (Fig. S2). For example, as of April 12, the United Kingdom (UK) was classified in Amber EU travel status and exhibited the lowest case burden per capita among the 31 European countries studied. We found that quarantine durations ranging between zero and five days would result in fewer imminent infections in the UK than would closed borders (Fig. 2A). Portugal was also at Amber status; sufficient quarantine durations for Portugal ranged between 2-7 days, including quarantines of at least six days for travelers from high-prevalence Czechia, Poland, and Hungary (Fig. 2B). Belgium and Italy-each with Red EU travel status - exhibited sufficient quarantine durations of zero to three days and zero to four days respectively (Fig. 2C-D). Dark-red EU travel status countries Cyprus and Hungary—with high prevalence — require quarantine durations of zero to five days and no quarantine respectively, with a travel ban from the UK and Norway into Cyprus (Fig. 2E-F). In general, we found that the recommended duration of travel quarantine increases with the ratio of the prevalence for the origin country relative to the destination country (Fig. 2G). In particular, destination countries with low prevalence (Amber status) should implement longer quarantine durations with a median of three days, whereas destination countries with high prevalence (Dark Red status) would require quarantine durations with a median of zero days. Similarly, the duration of travel quarantine required for travellers from origin countries with high prevalence (Dark Red status; median two days) was longer than for travellers departing from origin countries with moderate prevalence (Amber status; median zero days). In addition to prevalence of disease, travel volume has a significant impact on quarantine and testing regimes that are sufficient to enable travel without increasing within-country transmission (Fig. S2). For instance, a comparison of Belgium and Italy— both with Red status — reveals that sufficient quarantines to visit Italy would need to be longer, not only because of differences in prevalence, but also due to differences in typical travel volume associated with the popularity of Italy as a travel destination (Fig. 2C-D). The effect of travel volume is even stronger in a comparison of quarantine durations for two Dark Red status countries, Cyprus and Hungary (Fig. 2E-F). Travel from the UK to Cyprus is historically high; consequently, a ban on travel for visitors from the UK would be required to ensure transmission within Cyprus is not increased. For a few destination countries, we found that even a travel quarantine duration of 14 days would be insufficient to keep imminent infections equivalent to or lower than that achieved by a complete travel ban (Fig. 2G; Fig. S1). This result can arise when there is substantial asymmetry in the number of travellers abroad. For example, the 
medRxiv preprint doi: https://doi.org/10.1101/2021.04.25.21256082; this version posted May 7, 2021. The copyright holder for this preprint (which was not certified by peer review) is the author/funder, who has granted medRxiv a license to display the preprint in perpetuity.

It is made available under a CC-BY-NC-ND 4.0 International license .

average duration of stay for visitors to Turkey is 9.9 days [34], which is longer than $97 \%$ of stays in any of the other countries. In addition, substantially more travellers enter Turkey than residents of Turkey travel out. A large number of travellers in the country and fewer residents abroad leads to serious challenges in devising a sufficient quarantine and testing procedure that could maintain travel at typical levels. Sensitivity analysis of the sufficient quarantine duration for each parameter revealed that the disease prevalence in the destination and origin countries, number of daily travellers between the countries, and the fractional incidence (i.e. daily incidence per capita) in the destination country exhibited substantial impact on the quarantine duration (Fig. S2). The number of travellers abroad, natural immunity, and vaccine-induced immunity in both the origin and destination country had moderate impact, while age demographics and population size in the origin and destination countries had negligible effects on the duration of travel quarantine (Fig. S2).

We further evaluated the effect of opening borders for travel on hospitalization within the destination country. Using the estimated imminent infections as of April 12, we calculated the two-week hospitalization rate per 100,000 residents for each of the country pairings assuming a zero-day travel quarantine with an RT-PCR test, an antigen test, or no test. Regardless of the testing approach, we found that there was negligible change in the short-term two-week hospitalization rate for a destination country - a result that was robust irrespective of the prevalence in the origin country (Figs. S3-S7). Imposing an extensive travel quarantine of 14 days with an RT-PCR test on exit only nominally reduced the country-wide two-week hospitalization rate (Figs. S8-S11). Without testing, the maximum reduction in the two-week hospitalization rate was $8.8 \%$. Moreover, $84.3 \%$ of all country pairs exhibited less than a $1 \%$ reduction in the two-week hospitalization rate. With RT-PCR testing on exit, the maximum reduction in two-week hospitalization rate was 5.6\%, with $92 \%$ of all country pairs exhibiting less than a 1\% reduction. Correspondingly, there was little difference in the two-week hospitalization rates depending on permitting open travel or prohibiting travel (Fig. S7). 
A

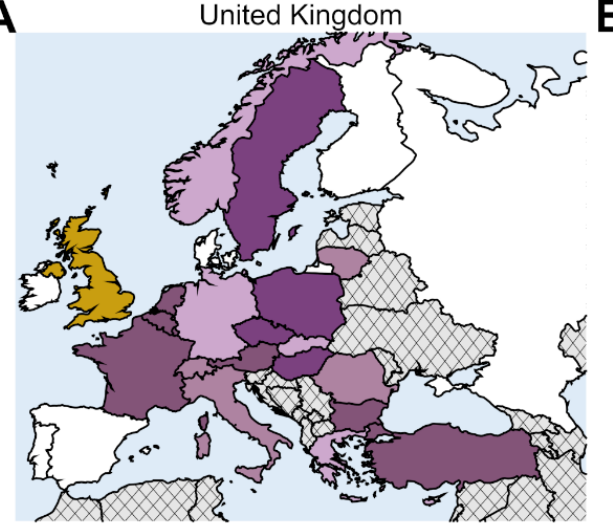

D

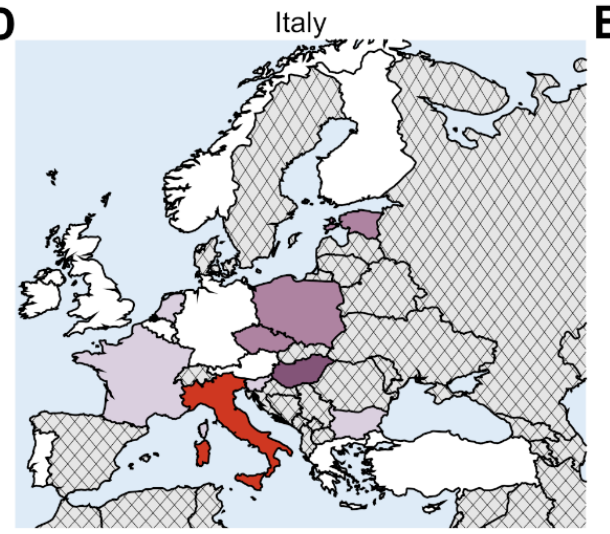

B

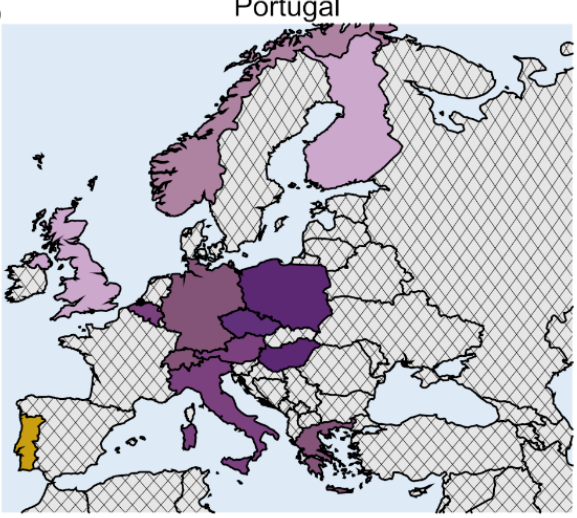

E

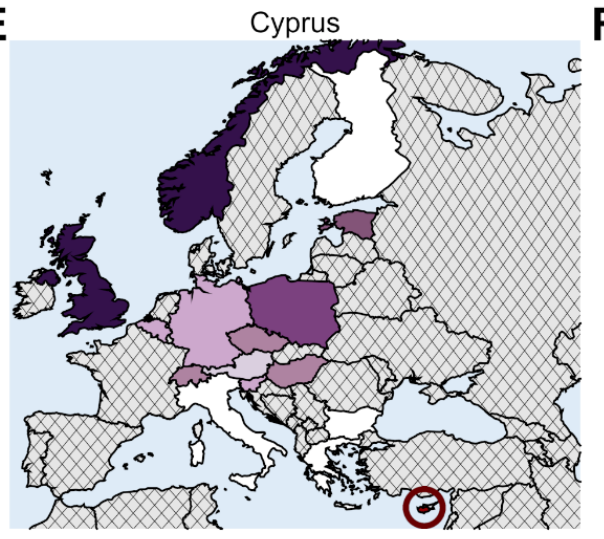

C

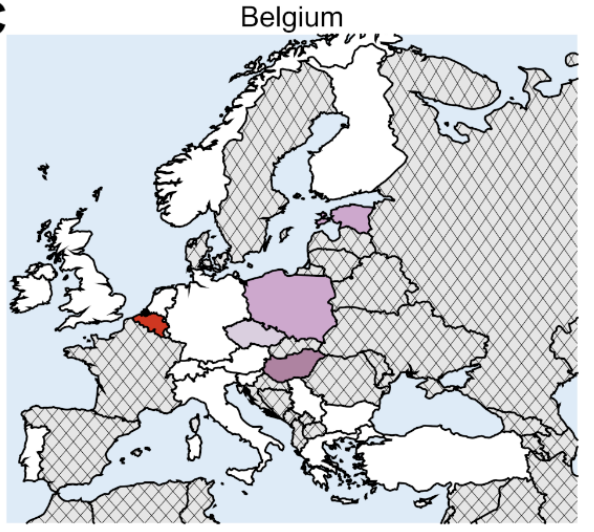

$\mathbf{F}$

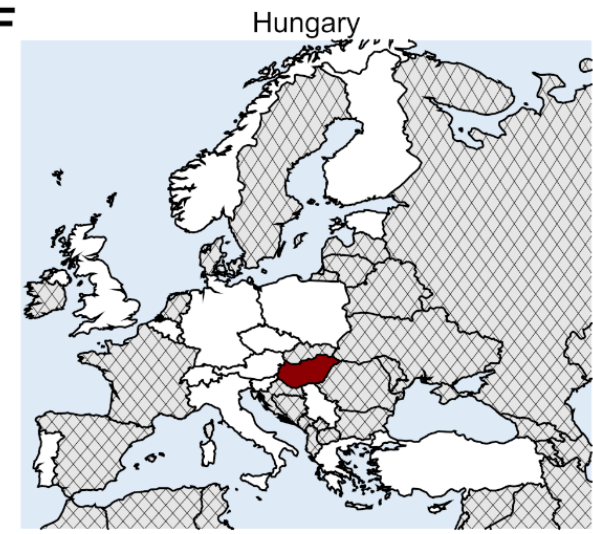

G

Origin country

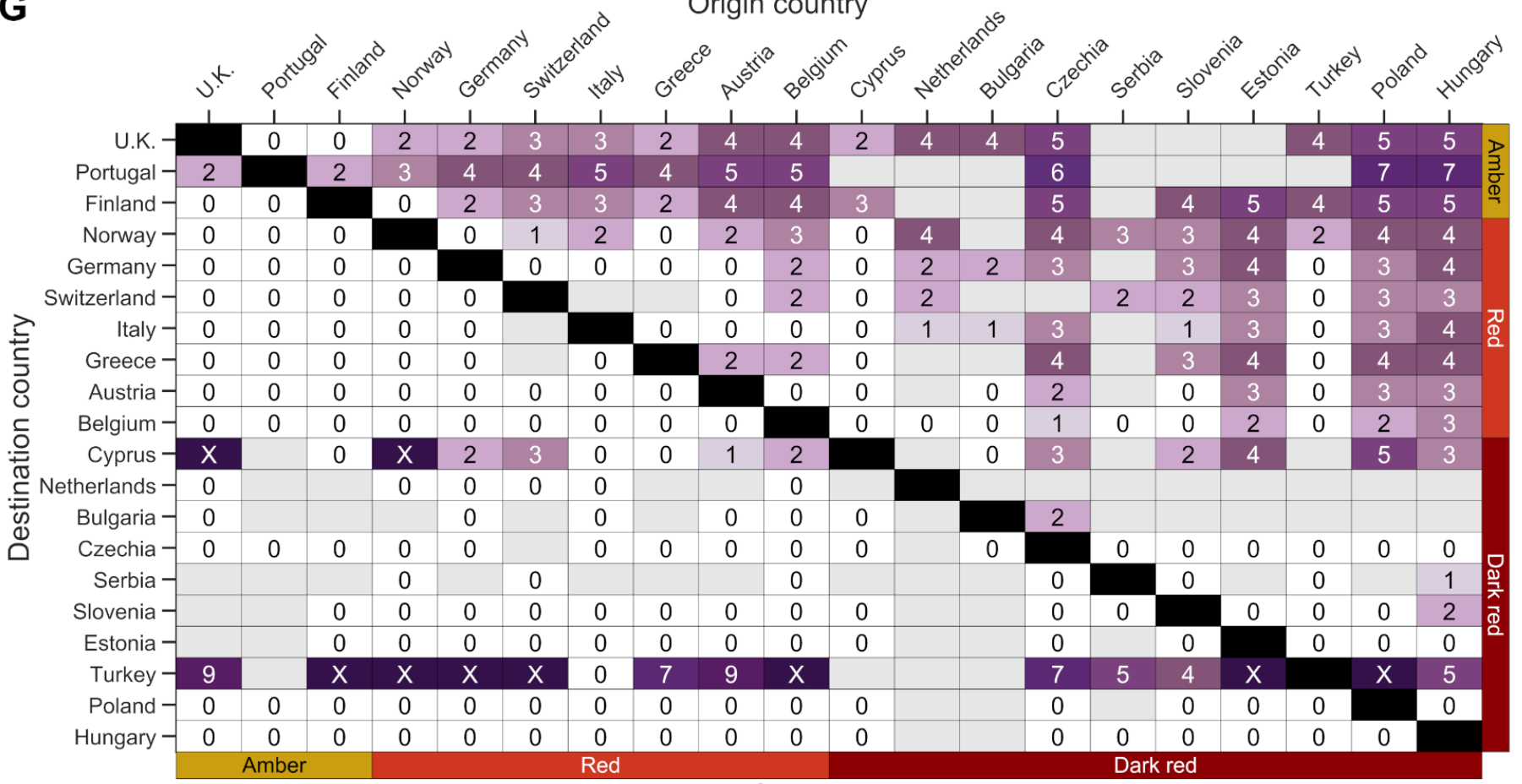

Country status

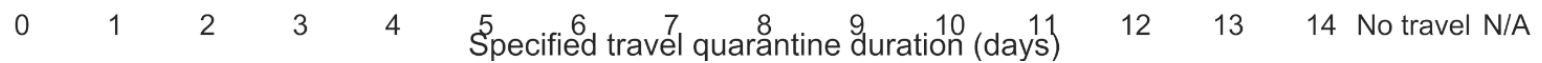


medRxiv preprint doi: https://doi.org/10.1101/2021.04.25.21256082; this version posted May 7, 2021. The copyright holder for this preprint (which was not certified by peer review) is the author/funder, who has granted medRxiv a license to display the preprint in perpetuity. It is made available under a CC-BY-NC-ND 4.0 International license .

Figure 2. The estimated minimum duration of travel quarantine for specified country pairs that reduces imminent infections to be equivalent to border closure. Specifying age-dependent vaccine efficacy and proportion of asymptomatic infections, as wells as country-specific demographics, incidence, prevalence of non-isolated infections, vaccine coverage, seroprevalence and travel flow, we determine the minimum duration of travel quarantine with an RT-PCR test on exit (colour gradient) that should be stated by the destination country for individuals arriving from the origin country. The countries are ranked based on their reported incidence per 100,000 over the last two weeks and stratified based on the European Union country classification system: Green, < 25 cases per 100,000; Amber, 25-150 cases per 100,000; Red, 150-500 cases per 100,000; and Dark Red, > 500 cases per 100,000. We consider travel quarantine durations of zero-days (white) to no travel (dark purple with "X", i.e., sufficient travel quarantine would exceed 14 days) for A) Portugal, B) the United Kingdom, C) Finland, D) Greece, E) Italy, F) Czechia, and G) 20 of 31 countries analyzed (cf. Fig. S1). Within-country travel quarantine is not evaluated in the analysis (black). Travel flow data was not available for all country pairs (gray). For quarantine durations of 1 day or longer, there was a 24-h delay in obtaining the RT-PCR test result. For a zero-day travel quarantine, there was assumed to be no delay in obtaining the RT-PCR test result.

\section{Variants of concern}

In our base case scenario (Fig. 2), we evaluated a general goal of eliminating the impact of travel on all imminent infections and did not distinguish among genetic variants or their characteristics. As variants of concern (VOC) emerge, they can be incorporated into the general framework or alternatively analyzed individually. Specifying $100 \%$ cross-immunity and no reduction in vaccine efficacy, we evaluated the impact of VOCs B.1.1.7 [36] and B.1.351 [37] at current estimates of their frequencies of circulation within the destination and origin countries [38], and quantified the sufficient duration of travel quarantine with the goal of no net increase in the incidence of VOCs or wild-type (Fig. 3 and

Fig. S12). Preventing both increased general transmission and increased transmission of VOCs within-country due to international travel would require lengthier quarantines and more travel restrictions compared to preventing general transmission alone (Fig. 3 vs Fig. 2G and Fig. S12 vs Fig. S1). The sufficient duration of travel quarantine increased substantially (median of six days vs median of zero days; Fig. S12 vs Fig. S1).

Because the effect of travel restriction on within-country hospitalization is so small (Fig. S3-S7), it may be warranted to focus travel policy on preventing an increase of within-country infections by specific VOC, incorporating any additional knowledge about the level or duration of infectiousness and test sensitivity. As of April 12, the highly contagious B.1.1.7. variant was widespread across much of Europe. Therefore, among countries with surveillance enabling estimation of the variant frequency, sufficient quarantine and testing is similar for this variant to that determined 
medRxiv preprint doi: https://doi.org/10.1101/2021.04.25.21256082; this version posted May 7, 2021. The copyright holder for this preprint (which was not certified by peer review) is the author/funder, who has granted medRxiv a license to display the preprint in perpetuity. It is made available under a CC-BY-NC-ND 4.0 International license .

for general transmission (Fig. 2G vs. Fig. 3A). In contrast, the B.1.351 VOC was at relatively low frequency in most European countries, with much greater variance in prevalence. Consequently, sufficient quarantine and testing would be more extreme and more distinct for this variant than that determined in a general analysis of COVID-19 transmission

(Fig. 3B vs. Fig. 2G and Fig. 3A). Combining concern for two variants leads to sufficient quarantines for each origin-destination pair determined by the maximum of those deemed sufficient for each variant (Fig. 3C). Consequently, incorporating additional VOCs into the goal of assuring no additional infections due to travel leads to potentially longer quarantines and significant travel restrictions (Fig. 3D).

A

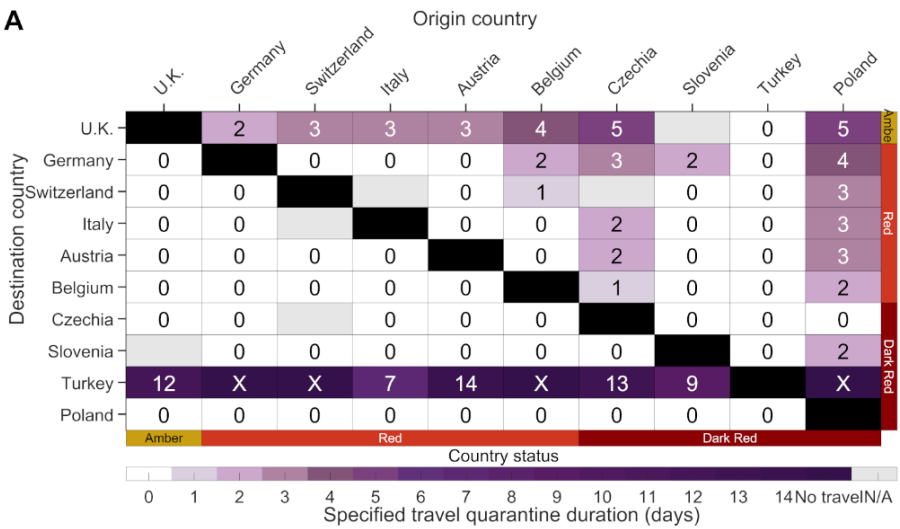

C

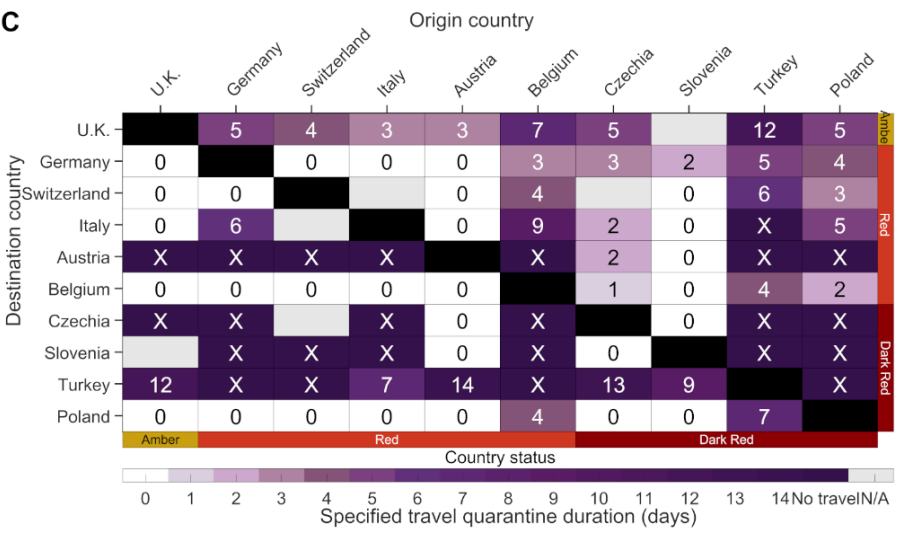

B

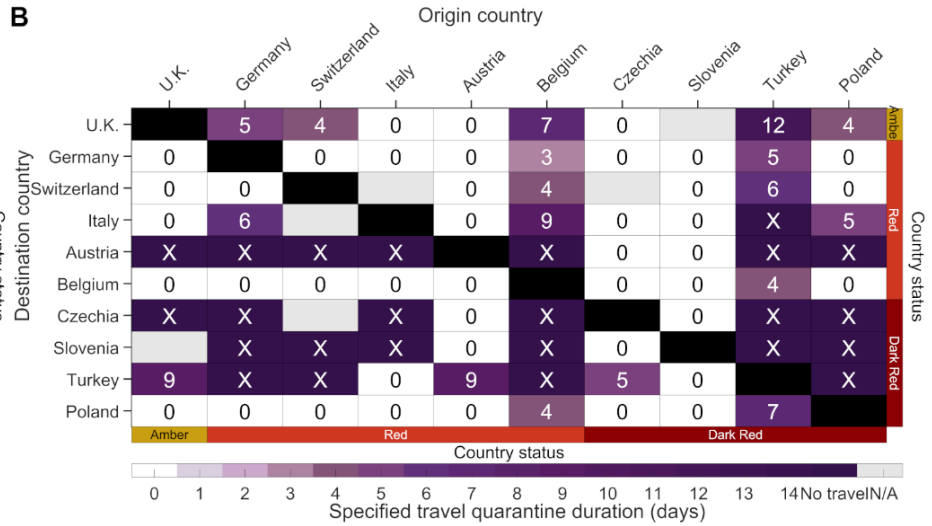

D

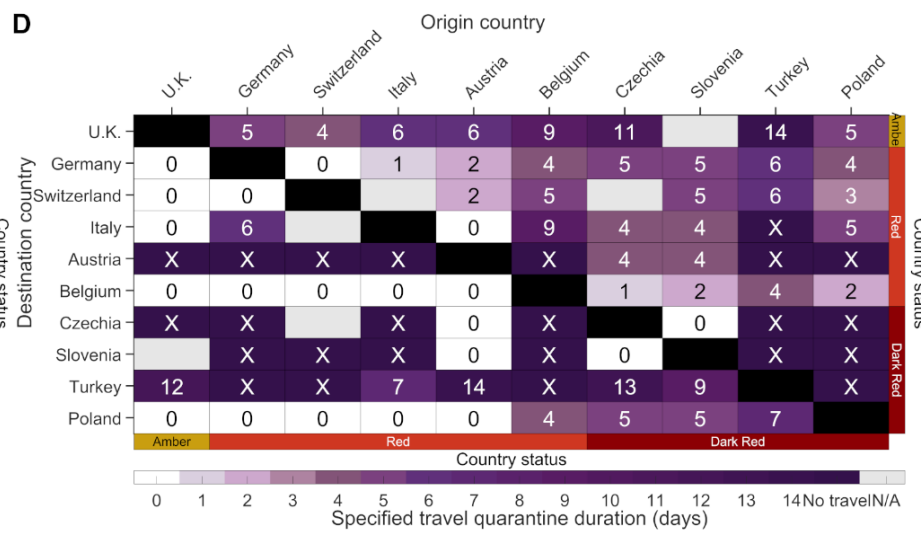

Figure 3. The estimated minimum duration of travel quarantine for specified country pairs that reduces imminent infections to be equivalent to banning travel when considering variants of concern. Specifying age-dependent vaccine efficacy and proportion of asymptomatic infections, as wells as country-specific demographics, incidence, prevalence of non-isolated infections, percentage of variants of concern, vaccine coverage, seroprevalence and travel flow, we determine the minimum duration of travel quarantine (colour gradient) that should be stated by the destination country for individuals arriving from the origin country when considering A) transmission of the variant of concern B.1.1.7.,

B) transmission of the variant of concern B.1.351, C) transmission of the variants of concern B.1.1.7 and B.1.351, and D) general transmission and transmission of the variants of concern B.1.1.7. and B.1.351. We consider travel 
medRxiv preprint doi: https://doi.org/10.1101/2021.04.25.21256082; this version posted May 7, 2021. The copyright holder for this preprint (which was not certified by peer review) is the author/funder, who has granted medRxiv a license to display the preprint in perpetuity.

It is made available under a CC-BY-NC-ND 4.0 International license .

quarantine durations of zero-days (white) to no travel (dark purple, i.e., specified quarantine can exceed 14 days). Within-country travel quarantine is not evaluated in the analysis (black). Travel flow data was not available for all country pairs (gray). The countries are ranked based on their reported incidence per 100,000 over the last two weeks and stratified based on the European Union country classification system: Green, < 25 cases per 100,000; Amber, 25 to 150 cases per 100,000; Red, 150-500 cases per 100,000; and Dark Red, > 500 cases per 100,000. For travel quarantine durations of 1 day or longer, there was a 24-h delay in obtaining the RT-PCR test result. For a zero-day travel quarantine, there was assumed to be no delay in obtaining the RT-PCR test result.

\section{Generalization of travel quarantine}

We next calculated sufficient quarantines based on the input used by the EU COVID risk classification system [35]. Setting population sizes, natural immunity, vaccine coverage, travel duration, and travel flow between countries to be the average of obtained data on the countries analyzed, we found that for origin countries at equal or lower COVID-19 status than the destination country, a zero-day travel quarantine with RT-PCR test is equivalent to or better than travel ban

(Fig. 4). As the ratio of the two-week case count in the origin country to the destination country increases, so does the specified duration of travel quarantine(Fig. 4). For origin countries with a greater number of infections per capita over the preceding two weeks than the destination country, the median duration of travel quarantine with an RT-PCR test on exit was three days, and durations ranged from one to six days (Fig. 4A).

Because testing approaches and quarantine durations vary across different countries, we compared sufficient travel quarantine durations under alternative strategies of no testing, a RT-PCR test conducted on exit, a rapid antigen test on exit, and a rapid antigen test on both entry and exit. Regardless of the testing approach, discrete tier categorization as opposed to quantitative calculation led to sufficiency of zero-day travel quarantine in any origin-destination pair for which the destination status was equivalent or worse than the origin status (Fig. 4; cf. Fig. 2G). Among origin countries with more infections per capita than the destination country, the median sufficient quarantine duration with no test was five days, and duration ranged from two to nine days (Fig. 4B). With an RT-PCR test on exit from quarantine, the sufficient quarantine duration reduced by a median of two days, and the decrease in the duration ranged from one to three days

(Fig. 4A). Switching to less-sensitive but inexpensive and logistically flexible rapid antigen tests yields results nearly identical to those determined using RT-PCR testing on exit (Fig. 4C vs. Fig. 4A). Only when the status of the destination country is Green and the status of the origin country is Dark Red does the sufficient quarantine duration exceed the RT-PCR test on exit duration by one day. Performing an antigen test on entry to quarantine in addition to exit eliminated 
medRxiv preprint doi: https://doi.org/10.1101/2021.04.25.21256082; this version posted May 7, 2021. The copyright holder for this preprint (which was not certified by peer review) is the author/funder, who has granted medRxiv a license to display the preprint in perpetuity.

It is made available under a CC-BY-NC-ND 4.0 International license .

that difference (Fig. 4A,D). We also quantified the effects of these alternative testing strategies in the context of our much more richly parameterized country-pair analysis (Fig. S13-S15), and found that these trends were largely consistent with the results obtained from a tier-based analysis (Fig. S16). Specifically, when the origin country was assigned lower-risk status than the destination country, the durations of quarantine for travelers from the origin country were equal to the median for equivalent country pairs in the tier-based analysis (Fig. S16). When the origin country was assigned higher-risk status, the tier-based analysis exhibited the same increasing trend of quarantine duration with increasing EU risk status as did the country-pair analysis. The greatest discrepancy was associated with the strategy of no testing for an Amber status destination country and Dark-Red status origin country (Fig. S16B), where the median of quarantine duration from the country-pair analysis was as much as three days longer than that determined from the tier-based analysis.

A

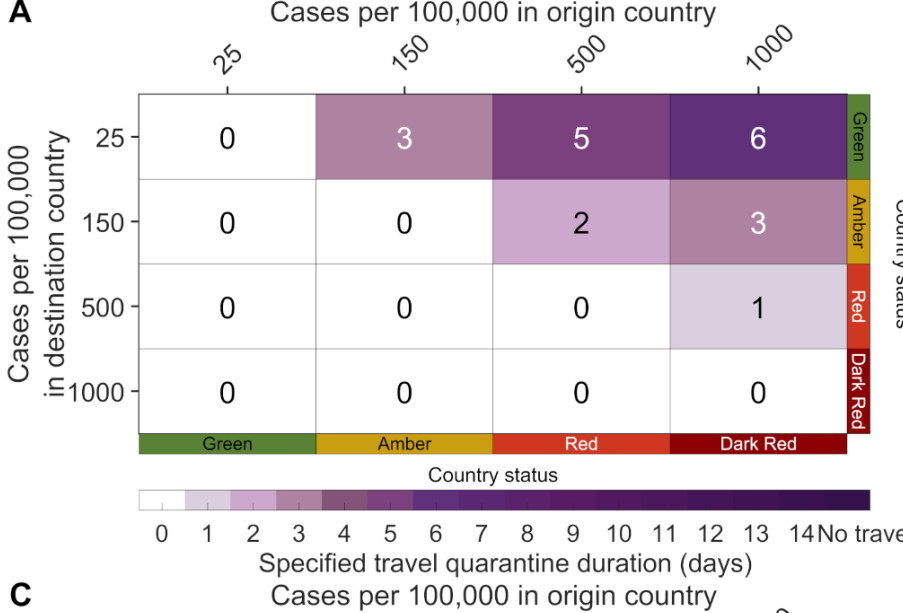

C

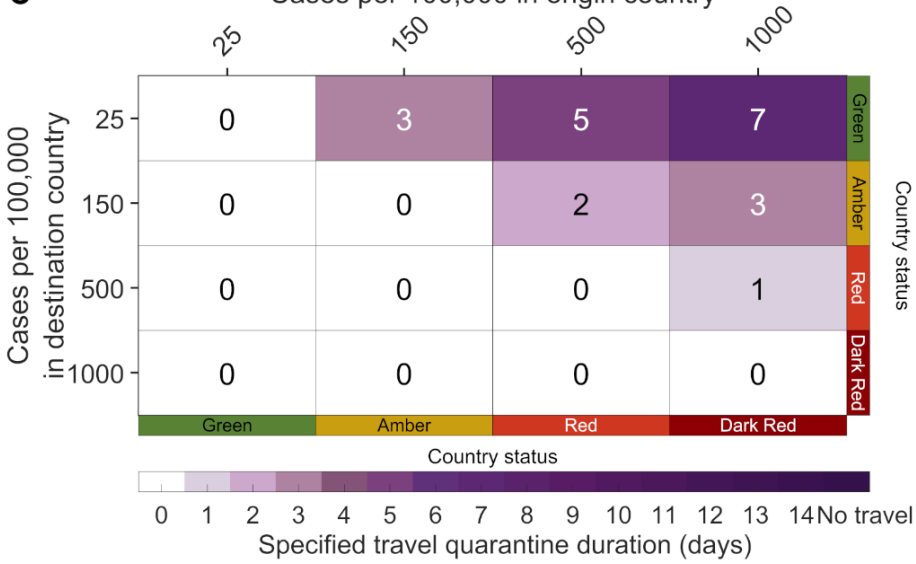

B

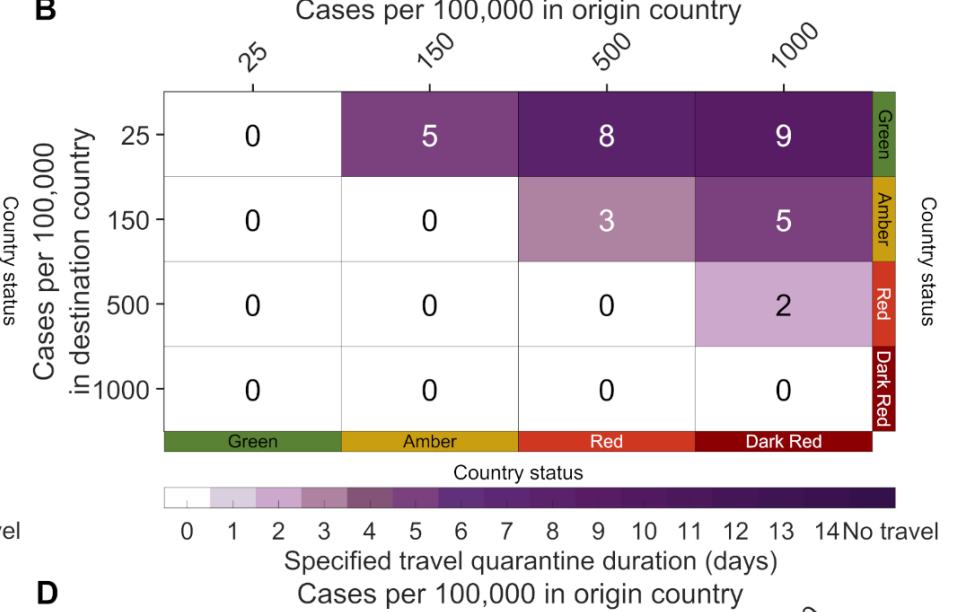


medRxiv preprint doi: https://doi.org/10.1101/2021.04.25.21256082; this version posted May 7, 2021. The copyright holder for this preprint (which was not certified by peer review) is the author/funder, who has granted medRxiv a license to display the preprint in perpetuity. It is made available under a CC-BY-NC-ND 4.0 International license .

Figure 4. Duration of travel quarantine for specified country pairs sufficient to prevent additional imminent infection due to travel, using prevalence associated with European Union traffic-light categorization of COVID-19 risk. Sufficient quarantine durations (colour gradient) are calculated including A) an RT-PCR test on exit, B) no testing, C) a rapid antigen test on exit, and $\mathbf{D}$ ) a rapid antigen test on both entry and exit, specifying age-dependent vaccine efficacy and proportion of asymptomatic infections, average European age structure, $17.6 \%$ vaccine coverage, and $18.8 \%$ natural immunity, for origin countries whose EU traffic-light status is Green (25 cases per 100,000), Amber (150 cases per $100,000)$, Red $(500$ cases per 100,000), or Dark Red $(1,000$ cases per 100,000$)$. For travel quarantine durations of one day or longer, there was a 24-h delay in obtaining the RT-PCR test result and no delay in obtaining the rapid antigen test. For a zero-day travel quarantine, there was assumed to be no delay in obtaining the RT-PCR test result.

We calculated the two-week hospitalization rate per 100,000 residents for vaccine coverage ranging from $0 \%$ to $100 \%$ within both the origin and destination country under the minimum specified travel quarantine duration (Fig. 5). For countries interested in setting quarantine duration based on hospitalization rates, instead of imminent infections, we considered an alternative threshold for the minimum travel quarantine that requires the two-week hospitalization rate to be equivalent or lower than the two-week hospitalization rate when there is no vaccination and no travel, assuming the destination country has a Green status. For origin countries that are not assigned Green status, this travel quarantine duration is shorter than that required under the criterion of imminent infections. We found that a longer travel quarantine based on the imminent infection criterion provides a minimal decrease in the two-week hospitalization rate when compared to zero-day travel quarantine (Fig. 5).

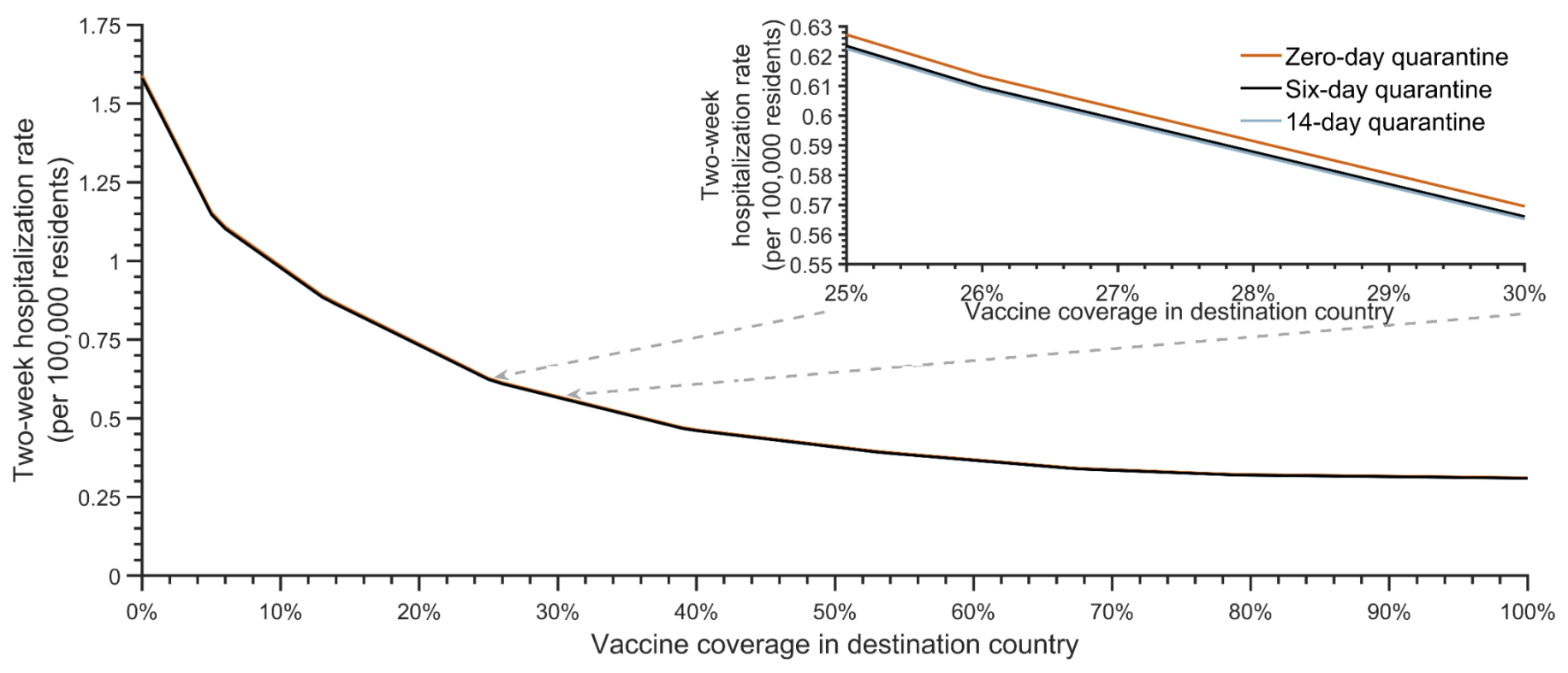


medRxiv preprint doi: https://doi.org/10.1101/2021.04.25.21256082; this version posted May 7, 2021. The copyright holder for this preprint (which was not certified by peer review) is the author/funder, who has granted medRxiv a license to display the preprint in perpetuity.

It is made available under a CC-BY-NC-ND 4.0 International license .

Figure 5. Expected two-week hospitalization rate per 100,000 residents in a Green-light destination country across varying vaccine coverage and travel quarantine durations. We calculated the projected two-week hospitalization rate for vaccine coverages between $0 \%$ and $100 \%$ (in both origin and destination), for a destination country whose traffic-light status is Green ( 25 cases per 100,000) visited by people from an origin country whose traffic-light status is Dark Red $(1,000$ cases per 100,000) with an RT-PCR test quarantine was zero days (orange), six-days (black) or 14 days (light blue) combined with an RT-PCR test on exit. For travel quarantine durations of one day or longer, there was a 24-h delay in obtaining the RT-PCR test result. For a zero-day travel quarantine, there was assumed to be no delay in obtaining the RT-PCR test result.

\section{Alternative diagnostic sensitivity curve for RT-PCR testing}

We examined the impact of an RT-PCR test on exit with an alternative temporal diagnostic sensitivity curve from Wells et. al. [7] on the minimum duration of quarantine (Figs. S17-S20). In the country-paired analysis, the median sufficient duration of quarantine with an RT-PCR test on exit was equivalent to the median duration from our baseline analysis. Furthermore, the sufficient duration of quarantine was shorter (by at most three days) than that in our baseline for $37 \%$ of the country pairings. In our tier-based analysis, the median sufficient duration of quarantine with an RT-PCR test on exit decreased from three days to two days, when the origin country was assigned higher-risk status. In this case, the sufficient quarantine duration was at most two days shorter when compared to our baseline.

\section{Discussion}

Here we have identified strategies of travel quarantine and testing that ensure in-country imminent transmission is no greater than would occur under a travel ban. We demonstrated that quarantines for European destinations that are specific to travel origin can be informed by country-specific prevalence, daily incidence, vaccine coverage, immunity, age-demographics, and travel flow. Our analysis indicated that for nearly half of these European country pairs, no quarantine or test is necessary to prevent increased imminent in-country transmission from travel, and for the majority, a test with no quarantine is sufficient. For many other origin-destination pairs, a travel quarantine of a few days paired with testing will suffice. The duration of travel quarantine is influenced mainly by the relative prevalence of disease between the two countries, the volume of travel, and the asymmetry of travel. With a goal of preventing the introduction of VOCs, quarantine and testing strategies that are sufficient for the general case will usually prevent imminent in-country VOC transmission as well. The strategies diverge when VOCs are infrequent and prevalence is heterogeneous on the international scale. 
medRxiv preprint doi: https://doi.org/10.1101/2021.04.25.21256082; this version posted May 7, 2021. The copyright holder for this preprint (which was not certified by peer review) is the author/funder, who has granted medRxiv a license to display the preprint in perpetuity.

It is made available under a CC-BY-NC-ND 4.0 International license.

Implementing travel quarantine and testing policies that are specific to many input parameters, dependent on country of origin as well as destination — and that change dynamically as waves of the pandemic strike and recede-is logistically challenging. Indeed, some countries have specified a single quarantine duration for any traveller entering their country $[39,40]$. However, such a policy may be unduly restrictive — or in some cases may not be restrictive enough. An intermediate approach is to simplify input parameters and discretize country classification in accordance with existing frameworks, such as the incidence-based EU Traffic Light system. By considering European averages for other parameters, we demonstrated the feasibility of mapping our more highly parameterized approach to the EU Traffic Light system. The agreement between our highly parameterized country-pair specific results and the results that we obtain mapping it to the prevalence-only EU Traffic Lights categories is imperfect. However, it provides analytical justification for decision-making that can otherwise be politicized rather than evidence-based.

Our analyses focused on imminent infection in comparison to travel ban, justifying the imposition of quarantine and testing regimes only insofar as they reduce in-country transmission more than would travel ban. However, whether the sufficient quarantine and testing strategies identified here are worthwhile from a public health or cost-effectiveness perspective requires additional consideration. For instance, high rates of hospitalization can overwhelm the healthcare infrastructure in a country. Thus, policy makers may want to apply travel quarantines to ensure that the hospitalization rate remains manageable. We found that two-week hospitalization rates in the destination country were not greatly influenced by where travellers are coming from or even by quarantine duration. This low impact is attributable to the relatively small numbers of travellers when compared with widespread infection among the resident population during a fully emerged pandemic [41]. In this circumstance, travel quarantines have an almost trivial impact on total in-country imminent infections and a proportionately small contribution toward hospitalization rate. A balanced consideration of quarantine duration should come both from an understanding of the relative impact of travel on infection and on the public health consequences of infections.

Our analysis focuses on the European region, where SARS-CoV-2 infection is already widespread. Globally, there are only a few instances where the virus has been forestalled at a national [22] or geographic border [42]. Over the majority of the pandemic, for instance, New Zealand has effectively maintained low COVID-19 case numbers [22]. Travel to New Zealand was restricted to citizens of New Zealand, who were only able to enter the country upon a negative test 
medRxiv preprint doi: https://doi.org/10.1101/2021.04.25.21256082; this version posted May 7, 2021. The copyright holder for this preprint (which was not certified by peer review) is the author/funder, who has granted medRxiv a license to display the preprint in perpetuity.

It is made available under a CC-BY-NC-ND 4.0 International license.

prior to departure, followed by a highly effective 14-day quarantine with two negative tests [7,43]. New Zealand aims to maintain closed borders with most of the globe until there is sufficient vaccine protection $[43,44]$. This strategy is supported by our analysis for a country with very low or zero reported daily incidence.

Similarly, our approach would indicate border closure by many countries early in the pandemic before global spread of infection-a closure that did not happen for a variety of geopolitical reasons, but also because of technological and supply limitations that prevented rapid, widespread, global testing. Even today, infections may be under-reported due to limited health resources and a high proportion of asymptomatic infections [45-48]. In part for this reason, the EU Traffic Lights system elevates their assessment of risk for countries that have high rates of test positivity. Disproportionate under-reporting of infections in the origin country relative to the destination would limit the informativeness of our analyses. To overcome this limitation, an analytical layer can be added that adjusts reported prevalence by test positivity $[48,49]$.

As the pandemic progresses, quarantine decisions may shift completely toward prevention of one or multiple variants of concern that are more transmissible or can escape natural and vaccine-mediated immunity [12]. Higher transmissibility and greater potential to escape vaccine-mediated immunity are both serious public health threats that may justify imposition of highly restrictive quarantine and testing regimes, or even border closure. Just as in the early COVID-19 pandemic [50], strong implementation could forestall variants of concern at the border. Accurate identification of variant properties is crucial, because attempting to forestall even a few different low-frequency variants would essentially entail complete border closure, which may be unnecessary if public health threat is minor. Therefore, genomic surveillance for variants of concern, and approaches to rapidly and accurately assess their epidemic properties, should be a priority so that decision-making regarding imposition of variant-related border quarantine and testing can be informed and judicious.

Although we have applied our analysis at a national level — where border controls are typically strongest and easiest to impose - our approach is not limited to travel between countries. It can be applied to any distinct population that can be monitored for the entry and exit of travellers. Furthermore, international quarantine and testing should not be considered a substitute for national policy preventing the spread of disease at a more localized scale within the country itself. Even if a 
medRxiv preprint doi: https://doi.org/10.1101/2021.04.25.21256082; this version posted May 7, 2021. The copyright holder for this preprint (which was not certified by peer review) is the author/funder, who has granted medRxiv a license to display the preprint in perpetuity.

It is made available under a CC-BY-NC-ND 4.0 International license .

0-day quarantine is sufficient between countries, widespread local travel may lead to infections where there were previously none [51].

The expected success of quarantine and testing can be undermined by non-compliance. It should be kept in mind that non-compliance is increased by the stringency of the requirement, so that it is possible to achieve less by requiring more. For example, some entrants to Canada opt not to comply with the stringent quarantine requirement [52-54]. As the first days of quarantine are often the most important to the prevention of SARS-CoV-2 transmission [7], it can be disadvantageous to public health goals to require a longer quarantine that elicits poor adherence instead of a shorter quarantine with improved compliance. Furthermore, these shorter individualized quarantion durations could free up resources that could then be better utilized to improve compliance through measures such as providing low-cost, safe accommodations and convenient, rapid, and accurate testing.

There is some controversy as to whether antigen testing can substitute for RT-PCR testing [55-57]. On the one hand, antigen tests provide quicker turnaround time and lower cost than RT-PCR tests and are also logistically easier to perform. On the other hand, antigen tests have lower sensitivity, a higher false-positive rate, and may result in missed cases. In our analysis, we accounted for the sensitivity of the tests along the disease time course and found that antigen tests can play a significant role in effective quarantine and testing. Except when the prevalence ratio was high between origin (Dark Red status) and destination (Green) country, the sufficient quarantine duration was the same whether antigen or RT-PCR test was used on exit. A major driver is the faster turnaround for the processing of antigen tests, which permits its use a day later in quarantine than the RT-PCR test. This feature enables its timing just before travel departure, while RT-PCR would need to be scheduled days in advance and therefore may miss an infection in its early stages [7]. We also showed that multiple rapid antigen tests could potentially be equivalent to or better than RT-PCR tests for prevention of post-quarantine transmission. Furthermore, use of an antigen test does not preclude one from sampling variants of concern, as positives can be referred for RT-PCR validation and genetic sequencing.

Our analytical approach to determining sufficient quarantines was designed to address the global COVID-19 pandemic. However, the model can be reparameterized with the dynamic infectiousness, sensitivity to testing, and other properties of other emerging diseases that may carry a global risk, to obtain policies of quarantine and testing that are sufficient to prevent increased in-country transmission in the context of global spread. Country borders would be specified 
medRxiv preprint doi: https://doi.org/10.1101/2021.04.25.21256082; this version posted May 7, 2021. The copyright holder for this preprint (which was not certified by peer review) is the author/funder, who has granted medRxiv a license to display the preprint in perpetuity.

It is made available under a CC-BY-NC-ND 4.0 International license .

to be closed during very early stages of pandemic spread, strictly controlling the quantity of travel associated with the epicenter. Border closure can markedly limit the global dissemination of the virus in the early stages [58], but has provided little demonstrated benefit once transmission becomes established in the country [4]. As the trajectory of a pandemic continues to unfold and country-specific prevalence, circulation of VOCs, and potentially vaccination coverage changes, travel quarantine strategies can be adjusted to assure equitable and safe international travel conditions between countries. In the unfortunate case of global spread, quarantines can be managed to prevent an increase in in-country transmission because of travel, as well as to enable effective and judicious response to new genetic variants of pandemic disease.

\section{Methods}

\section{Infectivity profile}

Our infectivity profile was based on 77 transmission pairs of COVID-19 cases from the computational code provided by He et al [59,60], specifying a latent period of 2.9 days and an incubation period of 8.29 days [7,20,21]. An age specified proportion $p_{A}$ of infections remains asymptomatic after the incubation period [17], with those exhibiting symptoms isolating and no longer producing infections. The duration of infectivity is 20 days after symptom onset [61-63], after which we specify the infectivity to be zero. A basic reproduction number of 2.5 was assumed [7], which reduced to an average of 2.1 when considering isolation upon symptom onset (based on the average age structure in Europe).

\section{COVID-19 test diagnostic sensitivity}

We use a similar methodology to Hellewell et al [64] to infer the temporal diagnostic sensitivity of the RT-PCR assay over the course of disease by fitting the diagnostic sensitivity curve of the RT-PCR assay to the results from serial testing (Supplementary Methods).

\section{Country epidemic profile}


medRxiv preprint doi: https://doi.org/10.1101/2021.04.25.21256082; this version posted May 7, 2021. The copyright holder for this preprint (which was not certified by peer review) is the author/funder, who has granted medRxiv a license to display the preprint in perpetuity.

It is made available under a CC-BY-NC-ND 4.0 International license .

We specify prevalence to be infections that are active and not isolated based on reported daily incidence (Supplementary methods). Seroprevalence estimates were used to determine the proportion of the population that is recovered and immune [22], and vaccine coverage determined vaccine-acquired immunity [19]. Those recovered or actively infected were assumed to vaccinate at equal frequency to those never infected.

\section{Long-term travel quarantine}

To evaluate the sufficient duration of travel quarantine for a specified testing strategy, we require the imminent number of infections under a travel ban to be greater than or equal to that when travel is allowed under the quarantine and testing scheme (Supplementary methods). Under a travel ban, the country-specific imminent infection is proportional to the fractional incidence, the effective reproduction number including non-immunological public health measures, and the level of immunity in the country. Country-specific imminent infection with long-term travel is composed of non-travelers and travelers, accounting for current disease burden, and level of immunity of both countries (Fig. 1). The daily contribution to imminent infections from residents and travellers — not previously infected—is dependent on the daily fractional incidence, number of people abroad, and the effective reproduction number. Residents and travellers who are leaving the destination andare infected, their number of imminent infections to be discounted depends on the daily number of travellers, prevalence of disease in the destination country, and the average residual extent of transmission. Residents returning and travellers entering the destination country add to the number of imminent infections, which is dependent on the daily number of travellers, prevalence of disease in the origin country, and the average residual extent of transmission after quarantine and testing.

\section{Travel quarantine strategies}

For our base case, we evaluated a travel quarantine strategy of 0-14 days quarantine duration with RT-PCR test conducted on exit. With the exception of zero-day quarantine, a delay of $24 \mathrm{~h}$ was assumed in obtaining results for an RT-PCR test (e.g. an RT-PCR test is conducted $24 \mathrm{~h}$ before exit from quarantine). We consider three alternative quarantine strategies: i) no testing, ii) antigen test on exit from quarantine, and iii) antigen test on entry to and exit from quarantine. 
medRxiv preprint doi: https://doi.org/10.1101/2021.04.25.21256082; this version posted May 7, 2021. The copyright holder for this preprint (which was not certified by peer review) is the author/funder, who has granted medRxiv a license to display the preprint in perpetuity.

It is made available under a CC-BY-NC-ND 4.0 International license .

When evaluating median quarantine durations across sets of country pairs for any of our results, a value associated with travel ban was accounted for, and was specified to be longer than 14 days.

\section{Vaccination, prevalence and hospitalization}

We assume that vaccination coverage initiates within the elderly age group $(\geq 80)$ and ends in the youngest age group (0-19).We specify age- and dose-specific efficacy in the reduction of documented infection $\left(\varepsilon_{\mathrm{a}, \mathrm{j}}\right)$ to determine the level of vaccine-acquired immunity. Specifying uniform natural immunity $(r)$ across age groups, age-specific prevalence of non-isolated infections was estimated based on the level of natural and vaccine-acquired immunity within all age classes (Supplementary methods). We utilize age-specific hospitalization probabilities estimated from the epidemic in France [65], the age demographics, and age-dependent efficacy in reduction of hospitalizations $\left(\omega_{\mathrm{a}, \mathrm{j}}\right)$ to estimate the hospitalization rate (Supplementary methods).

\section{Variants of concern}

We incorporated two known variants of concern, B.1.1.7 and B.1.351, in an additional analysis [38]. We consider increased transmission of the VOC relative to the general transmission, $100 \%$ cross-immunity, and no reduction in vaccine efficacy (Supplementary methods). When considering multiple variants of concern, the sufficient duration of travel quarantine was defined as the duration that satisfies the imminent infection inequality for all variants considered.

\section{Generalized Approach}

For generalized implementation of our modeling framework, we classified a country's status based on the EU traffic-light system - two-week caseload per capita and percentage of positive tests - utilizing the age demographics of Europe [66]. Based on the number of new cases in the past 14 days, a country's risk was stratified into Green (25/100,000), Amber (150/100,000), Red (500/100,000) and Dark Red (1,000/100,000). We assumed that the vaccination coverage in the origin country is the same as that in the destination country, and specified all parameters other than vaccine coverage and age demographics to be that of the average of the 31 European countries from our country-specific data (Supplementary methods). We assumed a single vaccine efficacy based on reduction in transmission and reduction in 
medRxiv preprint doi: https://doi.org/10.1101/2021.04.25.21256082; this version posted May 7, 2021. The copyright holder for this preprint (which was not certified by peer review) is the author/funder, who has granted medRxiv a license to display the preprint in perpetuity.

It is made available under a CC-BY-NC-ND 4.0 International license.

hospitalization from time of initial vaccine to the end of follow-up [18] (Table S5) to attain a generalized efficacy for individuals receiving either one dose or two doses, as to consider all scenarios of coverage of a second dose would be computationally intensive.

We also calculated the two-week hospitalization rates in the destination country under each scenario. Irrespective of their current risk category, the destination country was considered to want to keep their hospitalization rates consistent with the lowest risk category (Green). Therefore, we specified this threshold to be the rate of hospitalization for a destination country in Green status with $0 \%$ of vaccination coverage and no travel. We then calculated the minimum quarantine duration and resulting two-week hospitalization rates using this alternative threshold and compared it with the corresponding results obtained using imminent infections threshold.

Author contributions: CRW and JPT contributed equally to this work. JPT conceived and designed the study. JPT developed the theory with contributions from CRW and AP. CRW and WSC assembled relevant data. CRW wrote computational code, and executed analyses with contributions from AP. All authors contributed to interpretation of results. CRW, AP, and JPT drafted the manuscript. MCF, SMM and APG contributed to revision of the manuscript. All authors approved the final version of the manuscript.

Data availability: All data used in the analysis is referenced within the Methods and Supplementary Tables.

Competing interests: JPT and APG declare the following competing interests: received funding from an airline company to conduct research on travel quarantine durations. $\mathrm{CRW}, \mathrm{AP}, \mathrm{WSC}, \mathrm{MCF}$, and SMM declare no competing interest.

Acknowledgements: JPT and APG gratefully acknowledge research funding from EasyJet. JPT gratefully acknowledges funding from the Elihu endowment and the Notsew Orm Sands Foundation. MCF gratefully acknowledges funding from the National Institutes of Health (5 K01 AI141576). APG gratefully acknowledges funding from the Burnett and Stender families' endowment and the Notsew Orm Sands Foundation. 
medRxiv preprint doi: https://doi.org/10.1101/2021.04.25.21256082; this version posted May 7, 2021. The copyright holder for this preprint (which was not certified by peer review) is the author/funder, who has granted medRxiv a license to display the preprint in perpetuity.

It is made available under a CC-BY-NC-ND 4.0 International license .

Table 1. Parameter descriptions and references for determination of sufficient durations of travel quarantine

\begin{tabular}{|c|c|c|}
\hline Parameter & Definition & Reference \\
\hline$N_{T}$ & Country population size & {$[22]$} \\
\hline$N_{A}$ & The number of non-traveling and non-quarantined country-A residents & {$[22,24-34]$} \\
\hline$n_{B}$ & The number of residents of country B abroad in country A & {$[24-34]$} \\
\hline$n_{A B}$ & $\begin{array}{l}\text { The daily number of country-A residents returning from a long-term } \\
\text { visit to country B }\end{array}$ & {$[24-34]$} \\
\hline$R_{A}$ & Average imminent infection in country A & [7] \\
\hline$R_{Q_{A^{\prime} V}}$ & $\begin{array}{l}\text { Average 'left-over' imminent infection in country A of an infected } \\
\text { person who underwent the quarantine-and-testing regime } Q_{A}\end{array}$ & {$[7]$} \\
\hline$R_{V}$ & $\begin{array}{l}\text { Average 'left-over' imminent infection of an infected individual in } \\
\text { country A leaving at an unknown time in their infection period. }\end{array}$ & {$[7]$} \\
\hline$c_{A}$ & Daily fractional incidence in country A & {$[22]$} \\
\hline$\varrho_{\mathrm{A}}$ & Prevalence of non-isolated infections in country A & {$[22]$} \\
\hline$r_{A}$ & Proportion recovered in country A & {$[22]$} \\
\hline$v_{A}$ & Proportion of the population receiving at least one dose of the vaccine & {$[19]$} \\
\hline$\varphi_{A}$ & Proportion of the population immune to infection & {$[18,19,22]$} \\
\hline$p_{A}$ & Proportion of infections that are asymptomatic & {$[17]$} \\
\hline
\end{tabular}


medRxiv preprint doi: https://doi.org/10.1101/2021.04.25.21256082; this version posted May 7, 2021. The copyright holder for this preprint (which was not certified by peer review) is the author/funder, who has granted medRxiv a license to display the preprint in perpetuity.

It is made available under a CC-BY-NC-ND 4.0 International license .

\section{References}

1. Tognotti E. Lessons from the history of quarantine, from plague to influenza A. Emerg Infect Dis. 2013 Feb;19(2):254-9.

2. Linka K, Peirlinck M, Sahli Costabal F, Kuhl E. Outbreak dynamics of COVID-19 in Europe and the effect of travel restrictions. Comput Methods Biomech Biomed Engin. 2020 Aug;23(11):710-7.

3. Wells CR, Sah P, Moghadas SM, Pandey A, Shoukat A, Wang Y, et al. Impact of international travel and border control measures on the global spread of the novel 2019 coronavirus outbreak. Proc Natl Acad Sci U S A. 2020 Mar 31;117(13):7504-9.

4. Mallapaty S. What the data say about border closures and COVID spread. Nature. 2021 Jan;589(7841):185.

5. Abdulrahman A, AlSabbagh M, AlAwadhi A, Al-Tawfiq JA, Rabaan AA, Atkin S, et al. Quarantining arriving travelers in the era of COVID-19: balancing the risk and benefits a learning experience from Bahrain. Tropical Diseases, Travel Medicine and Vaccines. 2021 Jan 12;7(1):1-3.

6. Chinazzi M, Davis JT, Ajelli M, Gioannini C, Litvinova M, Merler S, et al. The effect of travel restrictions on the spread of the 2019 novel coronavirus (COVID-19) outbreak. Science. 2020 Apr 24;368(6489):395-400.

7. Wells CR, Townsend JP, Pandey A, Moghadas SM, Krieger G, Singer B, et al. Optimal COVID-19 quarantine and testing strategies. Nat Commun. 2021 Jan 7;12(1):356.

8. COVID-19: Border crossing information [Internet]. NSW Department of Industry. 2021 [cited 2021 Mar 10]. Available from: https://www.dpi.nsw.gov.au/home/covid-19/border-crossing-information

9. Transmission of SARS-CoV-2: implications for infection prevention precautions [Internet]. [cited 2021 Apr 27]. Available from: https://www.who.int/news-room/commentaries/detail/transmission-of-sars-cov-2-implications-for-infection-preventio n-precautions

10. Preparedness E. Considerations for quarantine of contacts of COVID-19 cases [Internet]. World Health Organization; 2020 [cited 2021 Apr 27]. Available from:

https://www.who.int/publications/i/item/considerations-for-quarantine-of-individuals-in-the-context-of-containment-f or-coronavirus-disease-(covid-19)

11. Kiang MV, Chin ET, Huynh BQ, Chapman LAC, Rodríguez-Barraquer I, Greenhouse B, et al. Routine asymptomatic testing strategies for airline travel during the COVID-19 pandemic: a simulation study. Lancet Infect Dis [Internet].

2021 Mar 22; Available from: http://dx.doi.org/10.1016/S1473-3099(21)00134-1

12. Abdool Karim SS, de Oliveira T. New SARS-CoV-2 Variants - Clinical, Public Health, and Vaccine Implications. N Engl J Med [Internet]. 2021 Mar 24; Available from: http://dx.doi.org/10.1056/NEJMc2100362

13. del Rio C, Malani P. COVID-19 in 2021—Continuing Uncertainty. JAMA. 2021 Apr 13;325(14):1389-90.

14. New coronavirus variants could cause more reinfections, require updated vaccines [Internet]. 2021 [cited 2021 Apr 26]. Available from:

https://www.sciencemag.org/news/2021/01/new-coronavirus-variants-could-cause-more-reinfections-require-updated -vaccines

15. Risk Assessment: Risk related to the spread of new SARS-CoV-2 variants of concern in the EU/EEA - first update 
medRxiv preprint doi: https://doi.org/10.1101/2021.04.25.21256082; this version posted May 7, 2021. The copyright holder for this preprint (which was not certified by peer review) is the author/funder, who has granted medRxiv a license to display the preprint in perpetuity.

It is made available under a CC-BY-NC-ND 4.0 International license .

[Internet]. 2021 [cited 2021 Apr 26]. Available from:

https://www.ecdc.europa.eu/en/publications-data/covid-19-risk-assessment-spread-new-variants-concern-eueea-firstupdate

16. Accelerated vaccine rollout is imperative to mitigate highly transmissible COVID-19 variants. EClinicalMedicine. 2021 May 1;35:100865.

17. Poletti P, Tirani M, Cereda D, Trentini F, Guzzetta G, Sabatino G, et al. Association of Age With Likelihood of Developing Symptoms and Critical Disease Among Close Contacts Exposed to Patients With Confirmed SARS-CoV-2 Infection in Italy. JAMA Netw Open. 2021 Mar 1;4(3):e211085-e211085.

18. Dagan N, Barda N, Kepten E, Miron O, Perchik S, Katz MA, et al. BNT162b2 mRNA Covid-19 Vaccine in a Nationwide Mass Vaccination Setting. N Engl J Med [Internet]. 2021 Feb 24; Available from: http://dx.doi.org/10.1056/NEJMoa2101765

19. Our World in Data. Data on COVID-19 [Internet]. [cited 2021 Apr 15]. Available from: https://github.com/owid/covid-19-data

20. Qin J, You C, Lin Q, Hu T, Yu S, Zhou X-H. Estimation of incubation period distribution of COVID-19 using disease onset forward time: A novel cross-sectional and forward follow-up study. Sci Adv. 2020 Aug;6(33):eabc1202.

21. Wang X, Pasco RF, Du Z, Petty M, Fox SJ, Galvani AP, et al. Impact of Social Distancing Measures on Coronavirus Disease Healthcare Demand, Central Texas, USA. Emerg Infect Dis. 2020 Oct;26(10):2361-9.

22. COVID-19 estimate downloads [Internet]. 2020 [cited 2021 Apr 15]. Available from: http://www.healthdata.org/covid/data-downloads

23. Kiesha P. Projecting contact matrices in 177 geographical regions: an update and comparison with empirical data for the COVID-19 era [Internet]. [cited 2021 Apr 15]. Available from: https://github.com/kieshaprem/synthetic-contact-matrices

24. MODUL University Vienna. City Tourism Recovery Monitor (Total foreign and domestic) [Internet]. TourMIS. [cited 2021 Mar 30]. Available from: https://www.tourmis.info/index_e.html

25. Travel trends estimates: UK residents` visits abroad - Office for National Statistics [Internet]. [cited 2021 Apr 15]. Available from:

https://www.ons.gov.uk/peoplepopulationandcommunity/leisureandtourism/datasets/ukresidentsvisitsabroad

26. Travel trends estimates: overseas residents in the UK - Office for National Statistics [Internet]. [cited 2021 Apr 15]. Available from:

https://www.ons.gov.uk/peoplepopulationandcommunity/leisureandtourism/datasets/overseasresidentsvisitstotheuk

27. Norway S. 08401: Accommodation establishments total. Guest nights, by guests' country of residence (C) (closed series) 2005M01 - 2019M12 [Internet]. StatBank. [cited 2021 Apr 21]. Available from:

https://www.ssb.no/en/statbank/table/08401/

28. Statistics Norway. Accommodation: guest nights at commercial and non-commercial establishments [Internet]. [cited 2021 Apr 21]. Available from: https://www.ssb.no/en/transport-og-reiseliv/reiseliv/statistikk/overnattingar

29. ÉTUDES ÉCONOMIQUES. 87 million foreign tourists in France in 2017 [Internet]. 2018 [cited 2021 Apr 21]. Available from: https://www.entreprises.gouv.fr/files/files/directions_services/etudes-et-statistiques/4p-DGE/2018-07-4p-N84-EVE-v ersion-anglaise.pdf 
30. Greece in Figures - ELSTAT. Arrivals and nights spent in hotels, similar establishments and tourist campsites (Final Data) [Internet]. [cited 2021 Apr 15]. Available from:

https://www.statistics.gr/en/greece-in-figures?p_p_id=com_liferay_portal_search_web_portlet_SearchPortlet_INSTA NCE_3\&p_p_lifecycle $=0 \& p \_p \_s t a t e=$ maximized\&p_p_mode $=$ view\&_com_liferay_portal_search_web_portlet_Sear

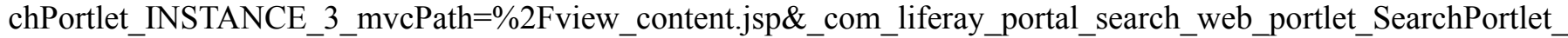
INSTANCE_3_assetEntryId=17020463\&_com_liferay_portal_search_web_portlet_SearchPortlet_INSTANCE_3_ty pe $=$ document

31. Greece in Figures - ELSTAT. Arrivals and nights spent in hotels, similar establishments and tourist campsites by Region and by country of residence [Internet]. 2019 [cited 2021 Apr 15]. Available from:

https://www.statistics.gr/en/greece-in-figures?p_p_id=com_liferay_portal_search_web_portlet_SearchPortlet_INSTA NCE_3\&p_p_lifecycle $=0 \& p \_p \_s t a t e=$ maximized $\& p \_p \_m o d e=v i e w \& \_c o m \_l i f e r a y \_p o r t a l \_s e a r c h \_w e b \_p o r t l e t \_S e a r$ chPortlet_INSTANCE_3_mvcPath=\%2Fview_content.jsp\&_com_liferay_portal_search_web_portlet_SearchPortlet_ INSTANCE_3_assetEntryId=17069628\&_com_liferay_portal_search_web_portlet_SearchPortlet_INSTANCE_3_ty $\mathrm{pe}=$ document

32. Key Tourism Facts 2019 [Internet]. Failte Ireland. 2021 [cited 2021 Apr 21]. Available from:

https://www.failteireland.ie/FailteIreland/media/WebsiteStructure/Documents/3_Research_Insights/4_Visitor_Insight s/KeyTourismFacts_2019.pdf?ext=.pdf

33. OECD. Istat Statistics [Internet]. [cited 2021 Apr 21]. Available from: http://dati.istat.it/?lang=en

34. Tourism Statistics, 4th Quarter: October-December and Annual, 2020 [Internet]. TURKSTAT. [cited 2021 Apr 13]. Available from: https://data.tuik.gov.tr/Bulten/Index?p=Tourism-Statistics-Quarter-IV:-October-December-and-Annual,-2020-37438

35. Department of Foreign Affairs. EU Traffic Lights Approach - Department of Foreign Affairs [Internet]. [cited 2021 Apr 15]. Available from: https://dfa.ie/travel/travel-advice/eu-traffic-lights-approach/

36. Galloway SE, Paul P, MacCannell DR, Johansson MA, Brooks JT, MacNeil A, et al. Emergence of SARS-CoV-2 B.1.1.7 Lineage - United States, December 29, 2020-January 12, 2021. MMWR Morb Mortal Wkly Rep. 2021 Jan 22;70(3):95-9.

37. Tegally H, Wilkinson E, Lessells RJ, Giandhari J, Pillay S, Msomi N, et al. Sixteen novel lineages of SARS-CoV-2 in South Africa. Nat Med. 2021 Feb 2;27(3):440-6.

38. GISAID - hCov19 Variants [Internet]. [cited 2021 Apr 15]. Available from: https://www.gisaid.org/hcov19-variants/

39. McMahon S. How 9 destinations around the world enforce mandatory quarantines. The Washington Post [Internet]. 2021 Feb 2 [cited 2021 Apr 20]; Available from: https://www.washingtonpost.com/travel/2021/02/02/quarantine-hotels-mandatory-covid/

40. Ledsom A. The Promise Of International Travel: April EU Travel Restrictions, Covid-19 Test Requirements, Quarantine By Country [Internet]. Forbes. 2021 [cited 2021 Apr 20]. Available from:

https://www.forbes.com/sites/alexledsom/2021/04/15/the-promise-of-international-travel-april-eu-travel-restrictions-c ovid-19-test-requirements-quarantine-by-country/

41. Chen S, Li Q, Gao S, Kang Y, Shi X. State-specific projection of COVID-19 infection in the United States and evaluation of three major control measures. Sci Rep. 2020 Dec 30;10(1):1-9.

42. Linka K, Rahman P, Goriely A, Kuhl E. Is it safe to lift COVID-19 travel bans? The Newfoundland story. Comput Mech. 2020 Aug 29;66(5):1081-92. 
medRxiv preprint doi: https://doi.org/10.1101/2021.04.25.21256082; this version posted May 7, 2021. The copyright holder for this preprint (which was not certified by peer review) is the author/funder, who has granted medRxiv a license to display the preprint in perpetuity.

It is made available under a CC-BY-NC-ND 4.0 International license .

43. de Jong E. New Zealand borders to stay closed until citizens are "vaccinated and protected." The Guardian [Internet]. 2021 Jan 26 [cited 2021 Apr 12]; Available from:

http://www.theguardian.com/world/2021/jan/26/new-zealand-borders-to-stay-closed-until-citizens-are-vaccinated-an d-protected

44. Reuters. New Zealand's borders may stay shut for most of the year, PM Ardern says [Internet]. CNN; 2021 [cited 2021 Apr 12]. Available from:

https://www.cnn.com/2021/01/26/asia/new-zealand-covid-borders-shut-intl-hnk/index.html

45. Alex Perkins T, Cavany SM, Moore SM, Oidtman RJ, Lerch A, Poterek M. Estimating unobserved SARS-CoV-2 infections in the United States. Proc Natl Acad Sci U S A. 2020 Sep 8;117(36):22597-602.

46. Angulo FJ, Finelli L, Swerdlow DL. Estimation of US SARS-CoV-2 Infections, Symptomatic Infections, Hospitalizations, and Deaths Using Seroprevalence Surveys. JAMA Netw Open. 2021 Jan 4;4(1):e2033706-e2033706.

47. Evaluating the massive underreporting and undertesting of COVID-19 cases in multiple global epicenters. Pulmonology. 2021 Mar 1;27(2):110-5.

48. Noh J, Danuser G. Estimation of the fraction of COVID-19 infected people in U.S. states and countries worldwide. PLoS One. 2021 Feb 8;16(2):e0246772.

49. Wu SL, Mertens AN, Crider YS, Nguyen A, Pokpongkiat NN, Djajadi S, et al. Substantial underestimation of SARS-CoV-2 infection in the United States. Nat Commun. 2020 Sep 9;11(1):1-10.

50. Yang J, Li J, Lai S, Ruktanonchai CW, Xing W, Carioli A, et al. Uncovering two phases of early intercontinental COVID-19 transmission dynamics. J Travel Med [Internet]. 2020 Oct 22 [cited 2021 Apr 25];27(8). Available from: https://academic.oup.com/jtm/article-pdf/27/8/taaa200/35282391/taaa200.pdf

51. Karatayev VA, Anand M, Bauch CT. Local lockdowns outperform global lockdown on the far side of the COVID-19 epidemic curve. Proc Natl Acad Sci U S A. 2020 Sep 29;117(39):24575-80.

52. Some travellers at Toronto airport fined for violating Ontario rules [Internet]. CBC. 2021 [cited 2021 Apr 12]. Available from: https://www.cbc.ca/news/canada/toronto/pearson-covid-toronto-airport-1.5927007

53. Goldfinger D. Public Health Agency of Canada "looking into" non-compliance incidents of new travel rules [Internet]. Global News. 2021 [cited 2021 Apr 16]. Available from:

https://globalnews.ca/news/7660045/phac-covid-19-quarantine-non-compliance-travellers/

54. Bhatia N, Sarwal S, Robinson H, Geduld J, Huneault F, Schreiner H, et al. Federal public health strategies to minimize the importation of communicable diseases into Canada. CCDR Supplement. 2015 Dec 17;41S-6:3-8.

55. Low performance of rapid antigen detection test as frontline testing for COVID-19 diagnosis. J Clin Virol. 2020 Aug 1;129:104455.

56. Pray IW. Performance of an Antigen-Based Test for Asymptomatic and Symptomatic SARS-CoV-2 Testing at Two University Campuses - Wisconsin, September-October 2020. MMWR Morb Mortal Wkly Rep [Internet]. 2021 [cited 2021 Apr 20];69. Available from: https://www.cdc.gov/mmwr/volumes/69/wr/mm695152a3.htm

57. Guglielmi G. Rapid coronavirus tests: a guide for the perplexed. Nature. 2021 Feb 9;590(7845):202-5.

58. Kang N, Kim B. The Effects of Border Shutdowns on the Spread of COVID-19. J Prev Med Public Health. 2020 Sep;53(5):293-301. 
medRxiv preprint doi: https://doi.org/10.1101/2021.04.25.21256082; this version posted May 7, 2021. The copyright holder for this preprint (which was not certified by peer review) is the author/funder, who has granted medRxiv a license to display the preprint in perpetuity.

It is made available under a CC-BY-NC-ND 4.0 International license .

59. He X, Lau EHY, Wu P, Deng X, Wang J, Hao X, et al. Temporal dynamics in viral shedding and transmissibility of COVID-19. Nat Med. 2020 May;26(5):672-5.

60. He X, Lau EHY, Wu P, Deng X, Wang J, Hao X, et al. Author Correction: Temporal dynamics in viral shedding and transmissibility of COVID-19. Nat Med. 2020 Sep;26(9):1491-3.

61. Xiao AT, Tong YX, Gao C, Zhu L, Zhang YJ, Zhang S. Dynamic Profile of RT-PCR Findings from 301 COVID-19 Patients in Wuhan, China: A Descriptive Study [Internet]. SSRN Electronic Journal. Available from: http://dx.doi.org/10.2139/ssrn.3548769

62. CDC. Interim Guidance on Duration of Isolation and Precautions for Adults with COVID-19 [Internet]. 2021 [cited 2021 Apr 13]. Available from: https://www.cdc.gov/coronavirus/2019-ncov/hcp/duration-isolation.html

63. Cevik M, Tate M, Lloyd O, Maraolo AE, Schafers J, Ho A. SARS-CoV-2, SARS-CoV, and MERS-CoV viral load dynamics, duration of viral shedding, and infectiousness: a systematic review and meta-analysis. Lancet Microbe. 2021 Jan;2(1):e13-22.

64. Estimating the effectiveness of routine asymptomtatic PCR testing at different frequencies for the detection of SARS-CoV-2 infections [Internet]. 2020 [cited 2021 Jan 13]. Available from:

https://cmmid.github.io/topics/covid19/pcr-positivity-over-time.html

65. Salje H, Tran Kiem C, Lefrancq N, Courtejoie N, Bosetti P, Paireau J, et al. Estimating the burden of SARS-CoV-2 in France. Science. 2020 Jul 10;369(6500):208-11.

66. Population Pyramids of the World from 1950 to 2100 [Internet]. [cited 2021 Apr 20]. Available from: https://www.populationpyramid.net/ europe/2019/ 